\title{
The factors affecting amniocentesis decision by pregnant women in the risk group and the influence of consultant
}

\author{
Kanay Yararbaş' (D) Ayşegül Kuşkucu² iD \\ ${ }^{1}$ Department of Medical Genetics, Faculty of Medicine, Acıbadem Mehmet Ali Aydinlar University, Istanbul, Turkey \\ ${ }^{2}$ Department of Medical Genetics, Faculty of Medicine, Yeditepe University, Istanbul, Turkey
}

\begin{abstract}
Objective: The most frequent goal for prenatal diagnosis is to detect pregnancies with Down syndrome. Since karyotyping, which is the golden standard for the diagnosis, has not been replaced with a non-invasive method, pregnant women in the risk group should choose the method such as CVS and amniocentesis. Therefore, screening tests are performed by non-invasive method, and pregnant women under risk are provided genetic consultation and the family is expected to make a decision for invasive procedure.

Methods: One thousand pregnant women who were at second trimester, provided genetic consultation in a reference center offering Perinatology and Medical Genetics clinical services, who were candidate for chromosomal analysis, but only had increased risk in biochemical screening or due to advanced maternal age were included in the study. The requests of partners, who were accompanying during genetic consultation, of the pregnant women who approved the procedure, invasive procedure decision and the factors affecting this decision were listed.

Results: We observed that the pregnant women came for genetic consultation with an accompanying individual as the pregnant women felt that they were in a stressful environment when they came for genetic consultation. More than half of the pregnant women $(52.1 \%)$ shared their decision right after genetic consultation. Almost two third of the pregnant women $(63 \%)$ stated that they decided to undergo amniocentesis. The factors affecting this decision are the worthiness of pregnancy in terms of the family and potential risks of invasive procedure in general.

Conclusion: Genetic consultation is one of the most important tools of patient-doctor relationship. It is very effective thanks to its informative nature especially for making a decision for invasive procedure in pregnant women and deciding for the progression of pregnancy upon invasive test results. In this study, we aimed to emphasize the significance on genetic consultation of knowing demographic distribution according to geographical characteristics of our country, and being aware that a population, which is diverse in terms of sociocultural aspects in particular due to the cosmopolite nature of metropolitan cities such as Istanbul, gets service.
\end{abstract}

Keywords: Genetic consultation, prenatal diagnosis, amniocentesis.

\section{Özet: Risk grubundaki gebelerin amniyosentez kararı almasındaki faktörler ve genetik danışmanın etkisi}

Amaç: Doğum öncesi tanıda günümüzde en sık amaçlanan hedef Down sendromlu gebelikleri tespit etmektir. Tanıda altın standart yöntem olan karyotiplemenin yerini henüz non-invaziv bir yöntem dolduramadığından, CVS, amniyosentez gibi bir yöntem için risk altındaki gebelerin seçimi gereklidir. Bu amaçla girişimsel olmayan yöntemlerle tarama testleri yapılmakta, riskli gebelere genetik danışma verilerek invaziv girişim kararı aileye bırakılmaktadir.

Yöntem: Perinataloji ve Tibbi Genetik klinik hizmetine sahip bir referans merkezde genetik danıșma verilen, kromozom analizi adayı; ancak sadece ileri anne yaşı ya da biyokimyasal taramada artmış riski olan, 1000 adet ikinci üç ay gebesi çalıșmaya dahil edildi. Onay veren gebelerin genetik danışma aldıkları sırada not alınan eşlik eden birey isteği, invaziv girişim kararı, bu kararı almasında etkili olan faktörler sıralandı.

Bulgular: Gebelerin genetik danışma almaya geldiklerinde bir stres ortamına giriyor hissine sahip olmaları nedeniyle, eşlik eden biriyle genetik danışma almayı tercih ettikleri görüldü. Gebelerin yarısından fazlası (\% 52.1) genetik danışma aldıktan sonra kararını paylaştı. Gebelerin neredeyse üçte ikisi (\%63) amniyosentez yaptırma kararı aldığını bildirdi. Bu kararı etkileyen faktörlerin dağılımı da genel olarak gebeliğin aile açısından kıymeti ve invaziv girişimin olası riskleri şeklinde sıralanabilir.

Sonuç: Genetik danışma tıb̆bi genetiğin en önemli hasta hekim ilişkisi araçlarından biridir. Özellikle gebelerde invaziv girişim kararı almada ve invaziv test sonuçlarıyla birlikte gebeliğin ilerlemesi konusunda karar vermede, bilgilendirici özelliği sayesinde çok etkili olmaktadır. Bu çalışmada ülkemizin coğrafi özelliklere göre demografik dağılımını bilmenin, İstanbul gibi büyük şehirlerde ise kozmopolit yapı nedeniyle, özellikle sosyokültürel açıdan çeșitlilik arz eden bir nüfusun hizmet aldığının farkında olmanın, genetik danışmadaki önemini vurgulamaya çalıştık.

Anahtar sözcükler: Genetik danışma, prenatal tanı, amniyosentez.

Correspondence: Kanay Yararbas, MD. Medical Genetics Department, Faculty of Medicine, Acıbadem Mehmet Ali Aydınlar University, Istanbul, Turkey. e-mail: kanayyararbas@gmail.com / Received: January 23, 2019; Accepted: January 31, 2019

Please cite this article as: Yararbaş K, Kuşkucu A. The factors affecting amniocentesis decision by pregnant women in the risk group and the influence of consultant. Perinatal Journal 2019;27(1):6-13. Perinatal Journal 2019;27(1):6-13. doi:10.2399/prn.19.0271001 


\section{Introduction}

Non-invasive methods in prenatal diagnosis have the characteristics of a prediction test before deciding invasive methods. ${ }^{[1]}$ These methods are: ${ }^{[2]}$

- First trimester combined test for Down syndrome

- Second trimester biochemical test for Down syndrome

- Maternal age-related screening only

- Perinatal ultrasonography screening

- Cell-free fetal DNA (cffDNA) screening in maternal blood

With the combination of all these methods with an effective genetic consultation, the families can make invasive procedure decision. ${ }^{[3]}$

The methods above are mainly the screening procedures for the detection of Down syndrome and other chromosomal aneuploidies, and it is aimed to determine chromosome structure of infant by using an invasive method, amniocentesis in particular, and to rule out a potential aneuploidy. Among them, cffDNA screening seems to be the most sensitive and specific method; however, its cost-benefit ratio is arguable. On the other hand, even this method has restrictions. ${ }^{[4]}$

The importance of genetic consultation is not only informing pregnant women about the options in a detailed and accurate way but also explaining the test results together with the restrictions accurately. ${ }^{[5,6]}$ The aim of the study is to compare and interpret the approaches and sociocultural characteristics of pregnant women that we provide genetic consultation in cases who call into doubt of the presence of aneuploidy fetus such as Down syndrome primarily but have biochemically increased risk of Down syndrome in first and second trimester screenings or due to advanced maternal age only. We conducted the study retrospectively by collecting the data of pregnant women who were provided genetic consultation in 2009.

\section{Methods}

A total of 1000 pregnant women who received genetic consultation in 2009 included in the study. All of these pregnant women were on the second trimester and candidate for amniocentesis. The distribution of these pregnant women according to referral reason is given in Fig. 1. The most common reasons were:

- Those found to have increased risk for Down syndrome in first and second trimester biochemical tests,
- Those not found to have any pathological ultrasound finding: Except those with nuchal translucency (NT) near the limits or soft marker ${ }^{[7]}$

- Advanced age

In brief, not the cases who were considered to have chromosomal disorders most likely but the pregnant women who were referred due to low and medium level risk and were about the make a decision were included in the study. Amniocentesis decision of these pregnant women depended on the decision of the family more than the pregnant women who would be recommended to have most likely an invasive procedure such as ultrasound findings of major anomaly and/or the pregnant women who would more likely have termination, and the genetic consultant was more influential. Therefore, although more than 3000 pregnant women were provided genetic consultation, most of them were not included in this study. Some of them were the pregnant women whose data could not be obtained during the consultations. The cases with pathological ultrasound finding, those referred for molecular genetic analysis, those who were at a gestational period later than (the cases who were recommended cordocentesis) or earlier than (the cases who were recommended CVS) second trimester, and the pregnant women who had consanguineous marriage

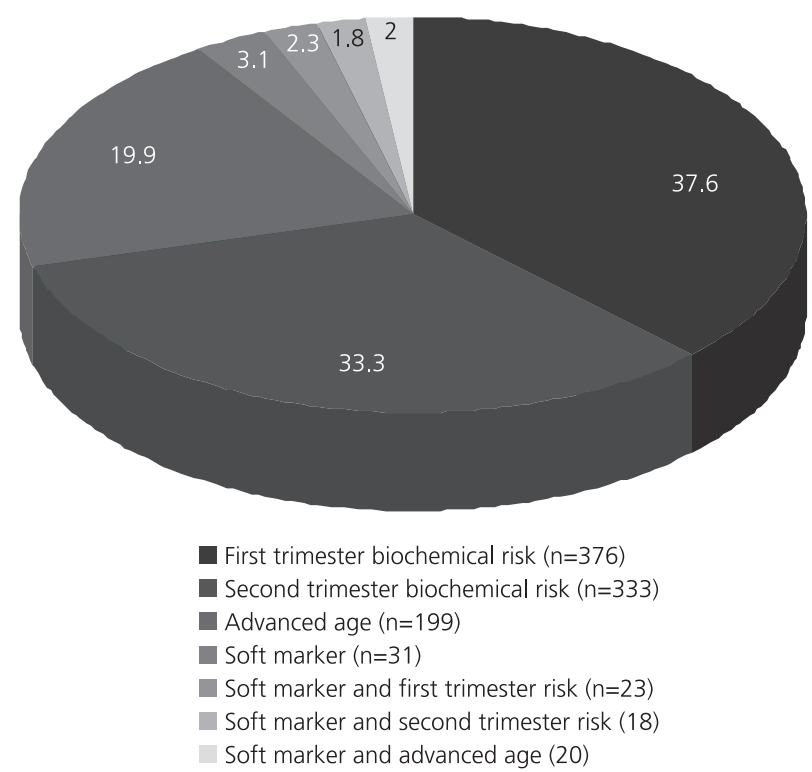

Fig. 1. The referral reasons of 1000 pregnant women. 
but were also informed for different aspects were excluded from this study.

All pregnant women were provided genetic consultation routinely, and they were delivered signed forms documenting that all available options were offered.

The ethics committee approval (no. 2017-13/53) of this retrospective study was obtained from the Medical Research Ethics Committee of Acrbadem University.

For deciding / not deciding for amniocentesis, the first decisions of the pregnant women which they shared with us verbally were taken into consideration.

\section{Results}

Most of the pregnant women participated in the consultation either alone $(519 / 1000)$ or with their husbands (191/1000) (Fig. 2). The pregnant women who came alone were said that they could participate in the consultation with their husbands; 71 pregnant women later readmitted with their husbands, 71 pregnant women readmitted alone and 14 pregnant women re-admitted with someone else and received genetic consultation. Of the pregnant women who were not alone or with their husbands, 166 came with a relative, 83 came with a relative of their husbands, and 41 came with an individual who was not a relative (Fig. 3). For the consultations, more than 2 people were not accepted due to physical conditions.

When the pregnant women who wanted to come with someone else other than their husbands were asked for the reason, they stated that:

- They were very stressed or excited,

- The person was someone they already share their secrets,

- They had to bring a family elder,

- They had difficulties to speak Turkish or express themselves.

After the consultation, most of the pregnant women made an instant decision and shared it with us (521/1000). While 191 of them said that they did not want to have amniocentesis (191/521), 330 of them said that they wanted to have amniocentesis (330/521) (Fig. 4).

When the clinical histories of the pregnant women $(\mathrm{n}=191)$ who did not want amniocentesis were reviewed, it was seen that almost half of them had a shared condition. Some of them were first pregnancy, and there were also the cases who got pregnant by using assisted repro- ductive technology and had the history of previous loss of pregnancy, and had miscarriage risk in this pregnancy (Fig. 5). Some of these pregnant women shared their opinions about why they did not want to undergo amniocentesis (Fig. 6). The most common reason was the fear of losing pregnancy due to amniocentesis including almost all of the pregnant women who had the history of a clinical condition (Fig. 5). Some pregnant women stated that they were motivated by the desire of delivering their babies under any circumstances according to their religious, cultural or personal beliefs. Some other pregnant women stated that they did not wonder the test results, and they preferred not to learn if their babies have any chromosomal anomaly or they did not have great expectations from the test results and they knew / now knew that chromosomal anomaly test could not eliminate congenital anomaly, mental retardation etc. alone. Some of them expressed that they understood that they were in the low risk group such as borderline age risk and therefore they were not afraid of pathological results.

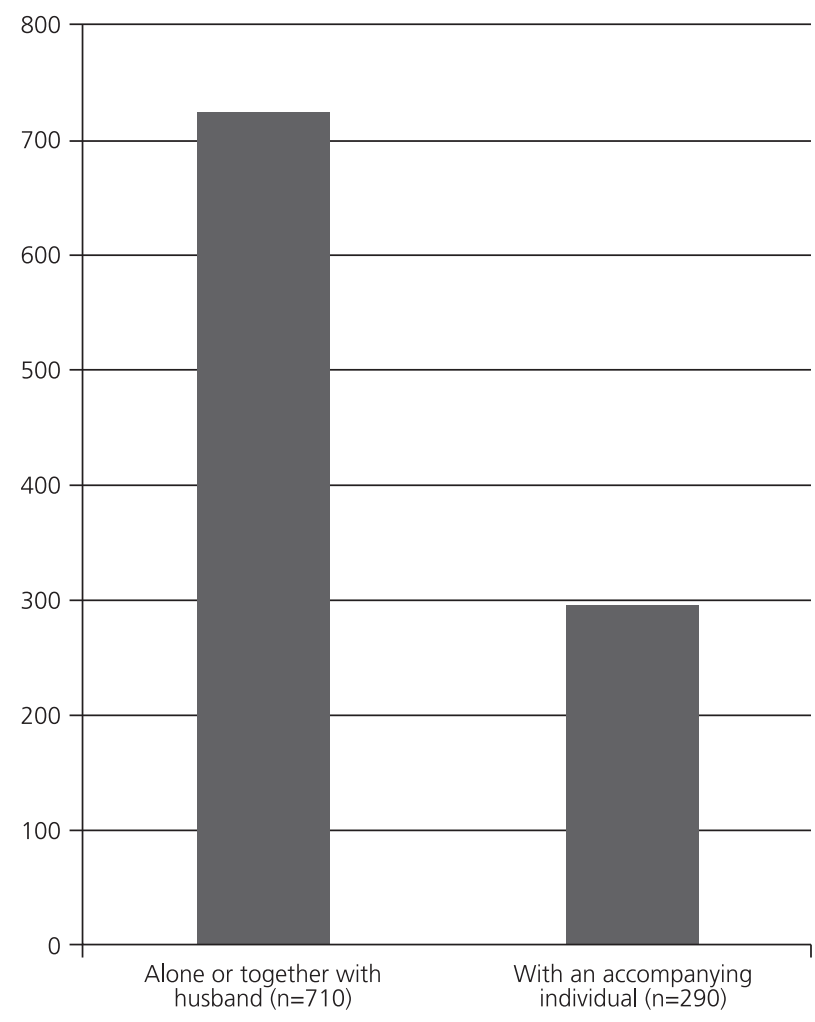

Fig. 2. Seventy-one percent of the pregnant women applied for genetic consultation either alone or with their husbands. 


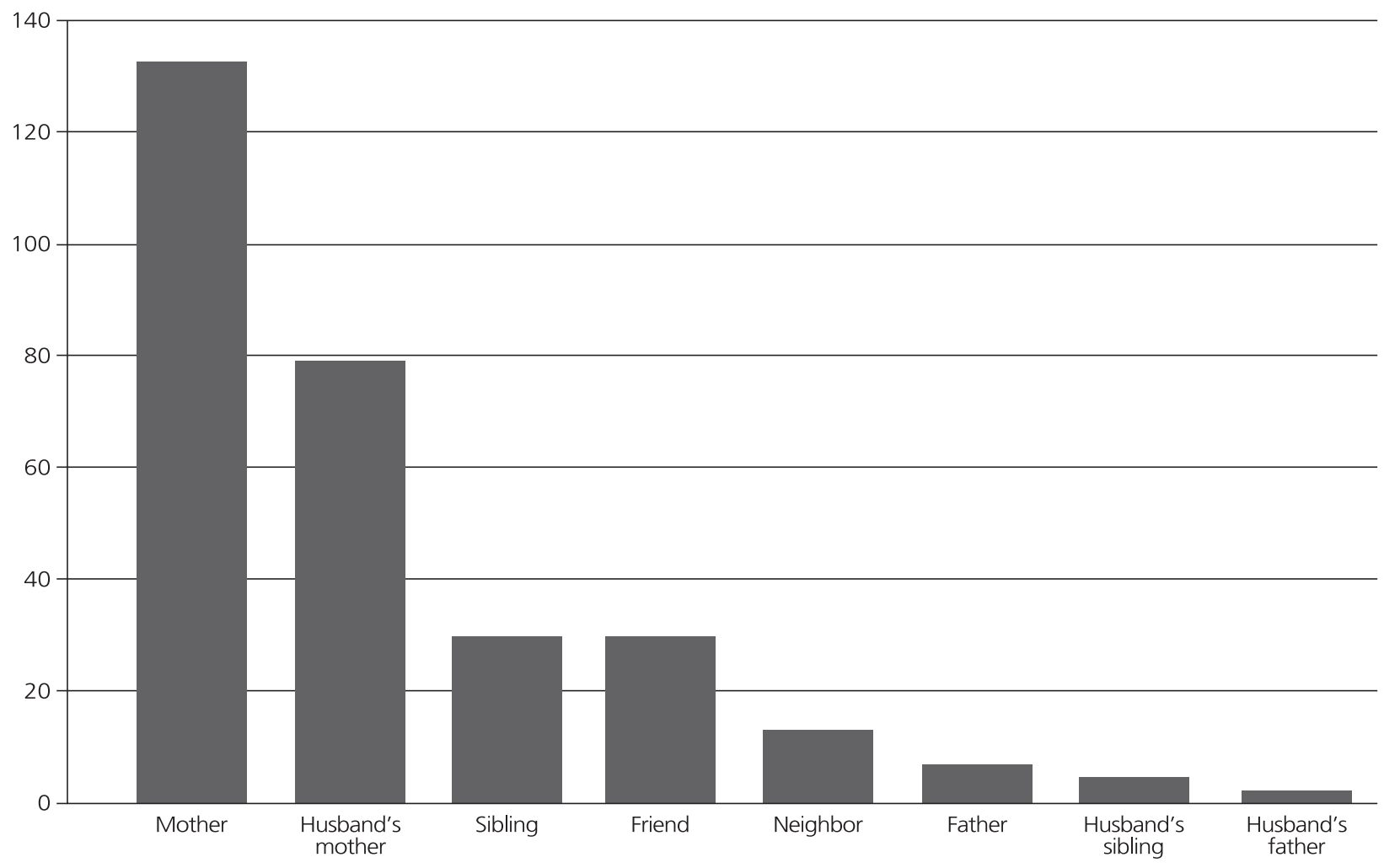

Fig. 3. Application with accompanying individuals.

The characteristics of the pregnant women who wanted to undergo amniocentesis were:

- Not desiring to deliver a disabled baby: Most of the pregnant women in this group had at least one healthy child. Some of them stated that the pregnancy was unwanted or unplanned pregnancy.

- Deciding its necessity: After genetic consultation, some of these pregnant women expressed that the consultation with us was the only factor for making a decision. A significant part of these pregnant women had soft marker in the ultrasound $\mathrm{d}^{[7]}$ in addition to age or biochemical test risk.

\section{Discussion}

Referring to screening tests in pregnancy follow-up and invasive method in cases suspected to have chromosomal anomaly is a routine approach. In all these conditions, genetic consultation is an important service and it should be provided to family in all stages. Genetic consultation which is tried to be improved technically all the time and be used more effectively ${ }^{[8]}$ is offered by the doctors who are medical genetic specialists in Turkey.

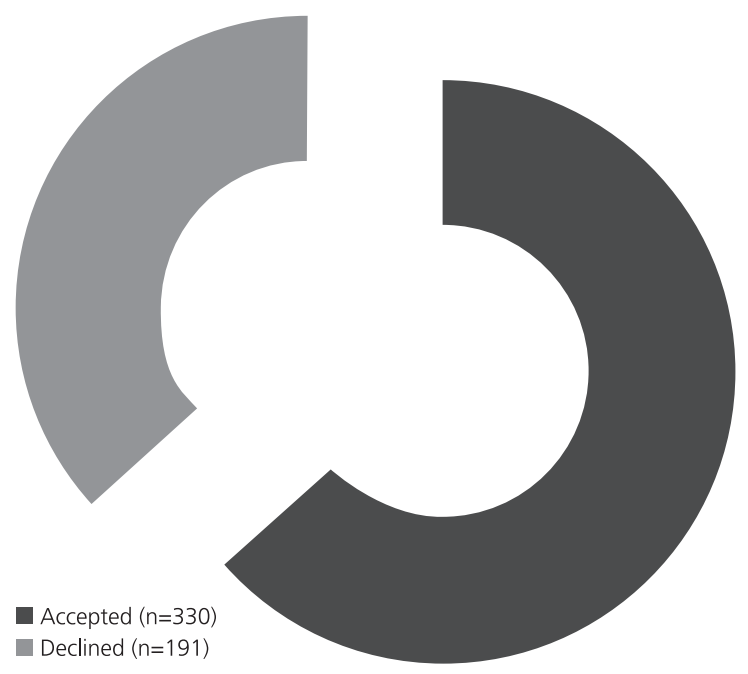

Fig. 4. Pregnant women who made instant decision about undergoing amniocentesis after genetic consultation $(n=521)$. 


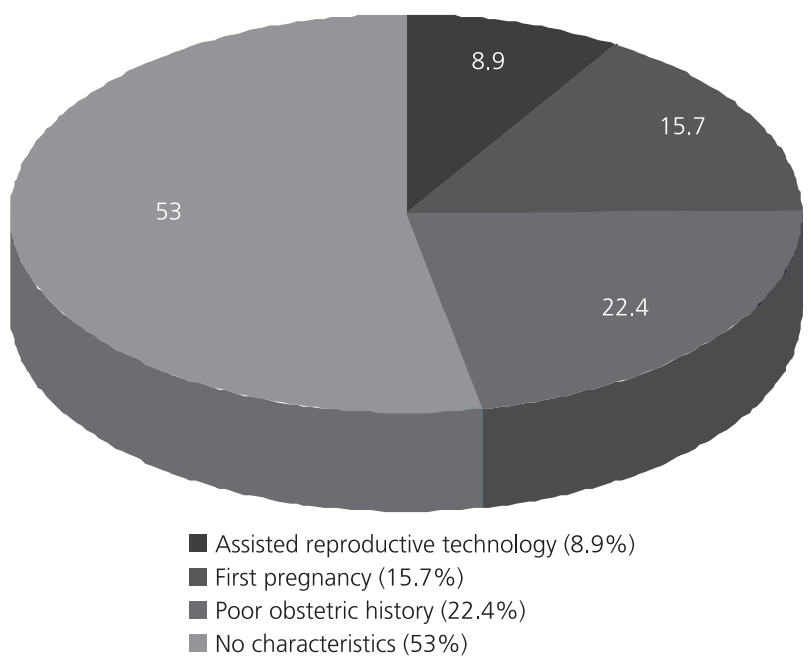

Fig. 5. Clinical characteristics of the pregnant women who did not want to undergo amniocentesis.

Educational level and social and cultural characteristics being spread to a wide spectrum in our country changes the feelings of families towards genetic consultation and the genetic consultant. There are also high numbers of pregnant women making a decision for invasive test with the influences such as religious beliefs and the views of family elders as well as the families who consider risk-benefit ratio according to the scientific data in our country. Another issue that should be taken into consideration in the conditions of our country is the geographical region. Both city and region differences and the distinction between city center and suburb in the same city affect such characteristics of patient population. These variables seem to be available in Asian populations, even in the members of families which immigrated to other countries. ${ }^{[9]}$ A physician offering genetic consultation should take all these characteristics in consideration. It is clear that this procedure, which is a kind of psychotherapy session, should be carried out in an unbiased and non-directive manner.

Since it is a multidisciplinary branch and it is understood today that almost all disease groups have a genetic background, patient groups from almost all medical discipline receive genetic consultation.

First trimester combined test has still been the preferred screening protocol in Turkey. In the last decade, it has been used more commonly for the screening of non-cell fetal DNA (cffDNA) in the maternal plasma,

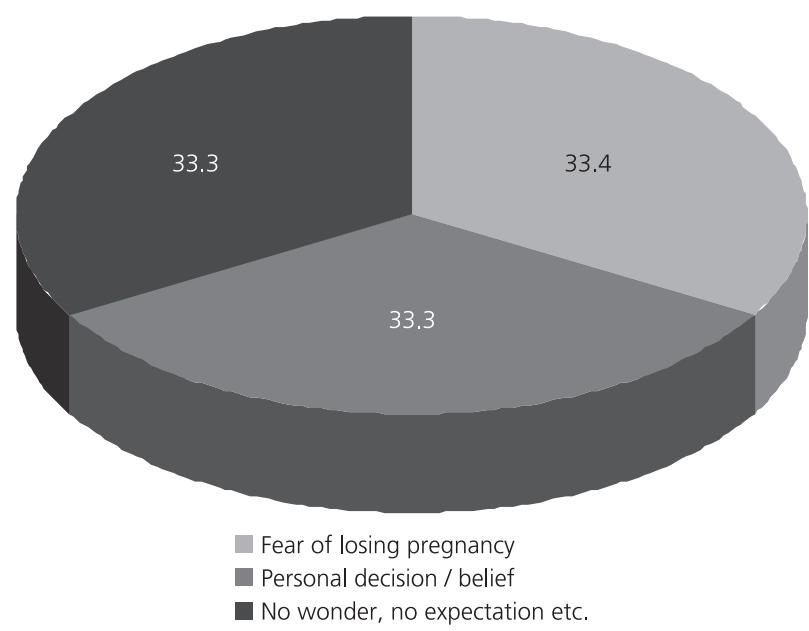

Fig. 6. Rejection reasons (they were classified equally to make it easy to understand; they do not represent actual numbers).

Down syndrome and other aneuploidies. Currently, cffDNA screening is far from being the first choice due to its high cost under today's conditions of Turkey. However, screening test opportunities being broad can be the greatest support for decision-making process of families. Since the rates of false negative results in terms of Down syndrome in particular are low, it has a potential to decrease the necessity of invasive procedure considerably. ${ }^{[10,11]}$

Sentimental values, beliefs, cultural characteristics and customs are also significant for the invasive procedure decision of families. This is a matter affecting all clinicians in modern medicine practices in the world. ${ }^{[12]}$ Furthermore, it is known that the patients tend towards spirituality not only during prenatal period but during terminal period in particular and it increases its importance in the relationship between patient and physician. $^{[13]}$

In Turkey, Simşek-Kiper et al. published an extensive study, which was planned as a questionnaire, about prenatal decision-making process. The study essentially aimed to discuss termination decision of pregnant women who had prenatal diagnosis. In the conclusion of the study which also provided statistical analysis as it is a systematized study, it was shown that the conditions such as referred geographical region and having a healthy child did not have a significant effect on decision-making process. ${ }^{[14]}$ 
During up to the mid-periods of the first decade of 21 st century where the efficiency of screening tests was lower, most of the pregnant women believed that invasive procedures for prenatal diagnosis was "a part of the routine", so they questioned the procedure less and accepted it more easily. ${ }^{[15-17]}$

In order for a genetic consultant to give healthy information, its standardization can be established. Introduction and meeting, informing about screening test, informing about diagnostic tests, and finally informing about the disease which is tested are generally accepted approaches for the procedure. ${ }^{[18]}$

The choices of 1000 pregnant women included in this study are important. Since it was tried to highlight the importance and impact of genetic consultation on decision-making process, the pregnant women without high risk increase were preferred first. Pregnant women with only advanced maternal age or whose nuchal translucency measurement is not above the upper limit, those with increased risk in their first or second trimester screening, or those without any finding in the perinatal ultrasonography creating suspicion for a prominent aneuploidy seem ideal for this choice. These pregnant women are the candidates to be a mother requiring less invasive procedure thanks to the cell-free fetal DNA screening in the maternal blood which have become prevalent today. Since this opportunity was not available during the period where the service was included in the study, the pregnant women were being referred to the perinatology outpatient clinic by the center conducting the routine pregnancy follow-up. When it was understood that there was no other finding besides soft marker ${ }^{[7]}$ particularly in the perinatal ultrasonography, the patients were being referred to the Medical Genetics Clinic for genetic consultation in order to explain that invasive procedure is just an option rather than recommending it directly. As a result, 1000 pregnant women were included in this study although genetic consultation was recommended for more than 3000 pregnant women during the year. Failing to provide sufficient information was one of the reasons for excluding more than 2000 pregnant women from the study. It could be possible to guide those with pathological ultrasound finding in terms of the necessity of invasive procedure; as a matter of fact, some of these pregnant women directly subjected to invasive procedure without recommending them genetic consultation. The pregnant women referred for molecular genetic analysis were the cases to be checked for a mutation, which was already detected in the family, and for which the procedure was already decided. We tried to establish a similar group in terms of gestational period; it was important for them to have equal evaluation opportunities in the perinatal ultrasonography. The pregnant women, who were at a later period than second trimester, probably had ultrasound finding detected later and/or referred later; most of them underwent cordocentesis procedure. They were the pregnant women who were at an earlier gestational period, namely in the first trimester, and have findings usually including nuchal translucency, and were already planned for a molecular analysis due to the family history. Pregnant women who had consanguineous marriage but were also informed on different matters were excluded from this study.

After the consultation, more than $50 \%$ of the pregnant women (521/1000) made a decision and shared it with us. This shows that genetic consultant is successful to help about half of these pregnant women, who received this service, for making their decisions. In a matter that they probably did not have any information, and in such a condition which most likely causes anxiety where their unborn child "may be disabled", it is shown that genetic consultation is an effective method in terms of informing patients and making them to make their own decision. Genetic consultation can be repeated. It is seen that 71 of the pregnant women who came alone readmitted together with their husbands for genetic consultation. This can be related with the desire of making a shared decision. We also know that 71 pregnant women came alone and 14 pregnant women re-admitted together with another individual for genetic consultation. Reassuring the families sufficiently that they can readmit to get information during decision-making process can be one of the most important goals of genetic consultation method.

We see that about $20 \%$ of the pregnant women who were evaluated in our center in this regard were referred due to advanced maternal age. This can be related with the distribution of socioeconomic level in the admissions made in related center. We conducted our study in the state training and research hospital which is a reference center. Most of the cases admitted to private centers may have higher education, a good career, married at an older age and/or decided to have child at an older age. In this case, the results of the study may change with center data where pregnancies at advanced ages are predominant rather than bio- 
chemical risks. Also, in admissions with accompanying individuals, some of the pregnant women expressed that it is compulsory to come with a family elder, and this statement is remarkable in terms of the sociocultural structure of our society. It is possible that these pregnant women are influenced by someone else when deciding for or declining amniocentesis procedure. The reason of having genetic consultation for some pregnant women with an accompanying individual is the communication difficulty in terms of language. Also, admitting reference center by the cases that come from different regions due to demographic characteristics is important in this respect. It should be kept in mind that the communication is carried out not with the accompanying individual but pregnant woman during genetic consultation. Non-verbal communication and eye contact should be maintained in order to provide a beneficial genetic consultation environment. Today, with the prevalent use of mass media, communication problem in Turkish has become a rare case among the admissions of young pregnant women; this issue is seen due to health tourism. Trying to provide a medical service such as genetic consultation, which is primarily based on communication, to a foreign individual through a translator may cause different issues. It is necessary to document genetic consultation notes and keep a written copy in medical records.

Our study has some limitations. Since proper records cannot be obtained in order to have statistical distribution of these opinions, we classified only qualitative data. It is important to understand that cffDNA test was not a routine practice in Turkey during the years when the study was conducted and the data were collected; because it is the screening test with highest sensitivity and specificity levels today. The availability of this test will possibly affect the quality and the results of genetic consultation. With the advancement of the technique, enrichment of the literature and publication of updated good practice guidelines, prenatal screening criteria such as the definition of soft marker have been changing over time. For example, soft marker identification and screening criteria are updated every 5 years in Australia. ${ }^{[19]}$ In our study, we questioned the decisions of pregnant women made after the clinic service but we did not follow up them, and therefore we could not calculate certain rates of those who actually underwent an invasive procedure; however, the documentation of the decision made by families after genetic consultation is important.
Re-designing the study and repeating it by up-todate screening methods and determining the rate of those who actually underwent invasive procedure, and adding genetic consultation details after the test and the attitude of families about maintaining or terminating pregnancy would create beneficial data for our country. Genetic consultation in prenatal diagnosis has gradually become significant as new technologies have been implemented and genetic analyses have become more inclusive. There are similar reports about this topic, even a small number of them; ${ }^{[20]}$ however, up-to-date reviews, ${ }^{[21]}$ and even good clinical practice guidelines are needed.

\section{Conclusion}

In general, there are three important factors affecting genetic test decision of pregnant women who receive genetic consultation before the test. These are the information obtained from genetic consultation, risk-benefit ratio, opinion about termination, and cultural factors. Therefore, it is very important for medical genetic expert to provide unbiased and non-directive genetic consultation and establish communication in order to enable the family to make their own decisions.

Conflicts of Interest: No conflicts declared.

\section{References}

1. Yararbas K, Ilgın-Ruhi H. Prenatal tanı. Türkiye Klinikleri Journal of Medical Sciences 2006;26:666-74.

2. Rizos D. Prenatal screening for chromosomal abnormalities: where do we stand today in Mediterranean countries? The Journal of the International Federation of Clinical Chemistry and Laboratory Medicine 2018;29:274-79.

3. Phadke SR, Puri RD, Ranganath P. Prenatal screening for genetic disorders: suggested guidelines for the Indian scenario. Indian J Med Res 2017;146:689-99.

4. Nshimyumukiza L, Menon S, Hina H, Rousseau F, Reinharz D. Cell-free DNA noninvasive prenatal screening for aneuploidy versus conventional screening: a systematic review of economic evaluations. Clin Genet 2018;94:3-21.

5. Stembalska A, Slezak R, Pesz K, Gil J, Sasiadek M. Prenatal diagnosis - principles of diagnostic procedures and genetic counseling. Folia Histochem Cytobiol 2007;45 Suppl 1:S11-6.

6. Vulic R, Culic V, Miskovic S, Gunjaca I, Roje D, Lasan R, et al. Prenatal diagnosis with genetic counseling in Uhc Split, Croatia. Int J Adv Res (Indore) 2017;5(3):1272-6.

7. Van den Hof MC, Wilson RD; Diagnostic Imaging Committee, Society of Obstetricians and Gynaecologists of Canada; Genetics Committee, Society of Obstetricians and 
Gynaecologists of Canada. Fetal soft markers in obstetric ultrasound. J Obstet Gynaecol Can 2005;27:592-636.

8. Cloutier M, Gallagher L, Goldsmith C, Akiki S, Barrowman $\mathrm{N}$, Morrison S. Group genetic counseling: an alternate service delivery model in a high risk prenatal screening population. Prenat Diagn 2017;37:1112-9.

9. Tsai GJ, Cameron CA, Czerwinski JL, Mendez-Figueroa H, Peterson SK, Noblin SJ. Attitudes towards prenatal genetic counseling, prenatal genetic testing, and termination of pregnancy among Southeast and East Asian women in the United States. J Genet Couns 2017;26:1041-58.

10. van der Steen SL, Houtman D, Bakkeren IM, Galjaard RJ, Polak MG, Busschbach JJ, et al. Offering a choice between NIPT and invasive PND in prenatal genetic counseling: the impact of clinician characteristics on patients' test uptake. Eur J Hum Genet 2019;27:235-43.

11. Watanabe M, Matsuo M Ogawa M, Uchiyama T, Shimizu S, Iwasaki N, et al. Genetic counseling for couples seeking noninvasive prenatal testing in Japan: experiences of pregnant women and their partners. J Genet Couns 2017;26:628-39.

12. Sagaser KG, Shahrukh Hashmi S, Carter RD, Lemons J, Mendez-Figueroa H, Nassef S, et al. Spiritual exploration in the prenatal genetic counseling session. J Genet Couns 2016; 25:923-35.

13. Balboni MJ, Sullivan A, Amobi A, Phelps AC, Gorman DP, Zollfrank A et al. Why is spiritual care infrequent at the end of life? Spiritual care perceptions among patients, nurses, and physicians and the role of training. J Clin Oncol 2013;31:4617.

14. Simsek-Kiper PO, Utine GE, Volkan-Salanci B, Alanay Y, Aktaş D, Alikaşifoğlu M, et al. Parental factors in prenatal decision making and the impact of prenatal genetic counseling: a study on Turkish families. Genet Couns 2014;25:53-62.

15. Fuchs KM, Peipert JF. First trimester Down syndrome screening: public health implications. Semin Perinatol 2005; 29:267-71.

16. Gates EA. Communicating risk in prenatal genetic testing. J Midwifery Womens Health 2004;49:220-7.

17. Tsianakas V, Liamputtong P. Prenatal testing: the perceptions and experiences of Muslim women in Australia. J Reprod Infant Psychol 2002;20:7-24.

18. Hodgson JM, Gillam LH, Sahhar MA, Metcalfe SA. "Testing times, challenging choices": an Australian study of prenatal genetic counseling. J Genet Counsel 2010;19:22-37.

19. Department for Health and Ageing, Government of South Australia. South Australian Perinatal Practice Guideline: ultrasound soft markers of aneuploidy [Internet]. Adelaide: Government of South Australia; 2018 July. Available from: https://www.sahealth.sa.gov.au/wps/wcm/connect/3358a5004 eee720fbe2ebf6a7ac0d6e4/Ultrasound+Soft+Markers+of+Ane uploidy_PPG_v3_0.pdf?MOD=AJPERES\&CACHEID=RO OTWORKSPACE-3358a5004eee720fbe2 ebf6a7ac0d6e4mxUXwaJ

20. İlgin Ruhi H, Yurur Kutlay N, Tukun A, Bokesoy I. The role of genetic counseling on decisions of pregnant women aged 35 years or over regarding amniocentesis in Turkey. Eur J Med Genet 2005;48:13-19.

21. Ilgin Ruhi H. Prenatal genetic counseling. Turkiye Klinikleri Journal of Medical Genetics-Special Topics 2018;3:121-5. 